\title{
Role of gelatinases MMP-2 and MMP-9 in tissue remodeling following acute lung injury
}

M. Corbel,

E. Boichot and

V. Lagente
IN SERM U 456, Laboratoire de Pharmacodynamie et de Pharmacologie Moléculaire, Faculté des Sciences Pharmaceutiques et Biologiques, Université de Rennes 1, Rennes, France

\section{Correspondence \\ V. Lagente \\ INSERM U 456 \\ Faculté des Sciences \\ Pharmaceutiques et Biologiques \\ Université de Rennes 1 \\ 2, Avenue du Professeur Léon \\ Bernard \\ 35043 Rennes cedex \\ France \\ Fax: + 33-299-33-6242 \\ E-mail: \\ vincent.lagente@ rennes.inserm.fr}

Presented at the XIV Annual Meeting of the Federação de Sociedades de Biologia Experimental, Caxambu, MG, Brasil, August 25-28, 1999.

Research supported by INSERM $M$. Corbel is the recipient of a grant from Conseil Régional de Bretagne, France.

Received December 16, 1999 Accepted March 22, 2000

\section{Abstract}

Acute lung injury is characterized by a severe disruption of alveolocapillary structures and includes a variety of changes in lung cell populations. Evidence suggests the occurrence of rupture of the basement membranes and interstitial matrix remodeling during acute lung injury. The dynamic equilibrium of the extracellular matrix (ECM) under physiological conditions is a consequence of the balance between the regulation of synthesis and degradation of ECM components. Matrix metalloproteinases (MMPs) represent a group of enzymes involved in the degradation of most of the components of the ECM and therefore participate in tissue remodeling associated with pathological situations such as acute lung injury. MMP activity is regulated by proteolytic activation of the latent secreted proenzyme and by interaction with specific tissue inhibitors of metalloproteinases. This review details our knowledge of the involvement of MMPs, namely MMP-2 and MMP-9, in acute lung injury and acute respiratory distress syndrome.

\section{Introduction}

Acute lung injury is characterized by lesions of both lung endothelial and alveolar epithelial cells leading in more severe cases to complete denudation of epithelial basement membranes. The most severe form of acute lung injury is the acute respiratory distress syndrome (ARDS). Despite substantial improvements in supportive care for patients with acute lung injury, the current mortality rate of ARDS appears to be in the 35 to $40 \%$ range (1). During the acute in-

\section{Key words}

- Matrix metalloproteinase

- TIMPs

- Acute lung injury

- ARDS

- LPS

- Extracellular matrix flammatory phase, basement membranes are also damaged with deposition of a provisional extracellular matrix (ECM) made of fibrinogen, fibronectin, and fibrillar collagens. Reconstitution of the alveolo-capillary barrier depends on a combination of events including proliferation of alveolar epithelial type II cells and their differentiation into type I pneumocytes. Re-epithelialization not only involves cellular proliferation and differentiation, but cellular locomotion as well. These processes are necessarily accompanied by digestion of the provisional matrix 
allowing its replacement by normal basement membranes, made of type IV collagen, laminin, and nidogen. All of these events would lead in the most favorable case to restoration of the normal alveolo-capillary barrier.

The ECM is a complex network composed of protein constituents including collagens and elastin, glycoproteins such as laminin, fibronectin, and nidogen, as well as various proteoglycans and glycosaminoglycans, which together build up the architecture of basement membranes and interstitium. The integrity of the ECM is controlled by a dynamic equilibrium between synthesis and local degradation of its different components. The matrix metalloproteinases (MMPs) are believed to be the main physiological mediators of ECM degradation. MMPs are expressed during physiological processes such as embryonic development and postnatal growth $(2,3)$ as well as in pathological conditions. In adult tissue, low level MMP expression mediates normal matrix remodeling, while during inflammation and injury, large amounts of MMPs are produced presumably to repair damaged ECM.

\section{Matrix metalloproteinases}

MMPs, also called matrixins (4), are zincdependent endopeptidases known for their ability to cleave one or several ECM constituents. They comprise a large family of nearly 20 members identified thus far that share common structural and functional elements and are products of different genes. These enzymes are primarily distinguished from other classes of proteinases by their dependence on metal ions and neutral $\mathrm{pH}$ for activity. Depending on substrate specificity, amino acid similarity and identifiable sequence modules, the family of MMPs can be classified into the following distinct subclasses (Table 1): collagenases (MMP-1, MMP-8, MMP-13), gelatinases (MMP-2, MMP-9), stromelysins (MMP-3, MMP-10, MMP-11), matrilysin (MMP-7), membranetype (MT)-MMPs (MT1-MMP, MT2-MMP, MT3-MMP, MT4-MMP), and elastase (MMP-12).

MMPs are secreted as proenzymes (latent form) and need activation to be fully functional. They have a propeptide domain (80 amino acids) which contains a conserved unique PRCGVPDV sequence. A cysteine

Table 1 - Classification of matrix metalloproteinases (MMPs).

\begin{tabular}{|c|c|c|c|c|}
\hline Subgroup & MMP & Nomenclature & Mass (kDa) & Matrix substrates \\
\hline \multirow{3}{*}{$\begin{array}{l}\text { Interstitial } \\
\text { collagenases }\end{array}$} & MMP-1 & Fibroblast & 52 & Fibrillar collagen (III>I) \\
\hline & MMP-8 & Neutrophil & 75 & Fibrillar collagen (I>III) \\
\hline & MMP-13 & Collagenase-3 & 54 & Fibrillar collagen \\
\hline \multirow[t]{2}{*}{ Gelatinases } & MMP-2 & Gelatinase A & 72 & Collagen I, IV, V, gelatin \\
\hline & MMP-9 & Gelatinase B & 92 & Collagen IV, V, gelatin \\
\hline \multirow[t]{4}{*}{ Stromelysins } & MMP-3 & Stromelysin-1 & 57 & $\begin{array}{l}\text { Laminin, fibronectin } \\
\text { Non-helical collagen }\end{array}$ \\
\hline & MMP-10 & Stromelysin-2 & 53 & Same as above \\
\hline & MMP-11 & Stromelysin-3 & 65 & Collagen IV, gelatin, laminin \\
\hline & MMP-7 & Matrilysin & 28 & Similar to MMP-3 \\
\hline \multirow[t]{4}{*}{ MT-MMPs } & MMP-14 & MT1-MMP & 66 & $\begin{array}{l}\text { Collagen I, II, III, gelatin } \\
\text { Activate MMP-2 }\end{array}$ \\
\hline & MMP-15 & MT2-MMP & 76 & $?$ \\
\hline & MMP-16 & MT3-MMP & 70 & Activate MMP-2 \\
\hline & MMP-17 & MT4-MMP & $?$ & $?$ \\
\hline Elastase & MMP-12 & Metalloelastase & 54 & Elastin, fibronectin \\
\hline
\end{tabular}


residue in this sequence maintains the latency of the zymogen by direct coordination with the active site zinc atom of the catalytic domain, blocking the access of the catalytic site to the substrate (5). Interruption of this interaction by aminophenylmercuric acetate, $\mathrm{HgCl}_{2}, \mathrm{HOCl}$, oxidized glutathione, by heat treatment, or by other proteases, including MMPs, initiates a cascade of events that alters the conformation of the protein. Following opening of the cysteine- $\mathrm{Zn}$ bond, a series of autocatalytic cleavages result in excision of the remainder of the propeptide to yield a proteolytically truncated and catalytically competent enzyme.

\section{Inhibition of matrix metalloproteinases}

The major physiologic inhibitors of the MMPs in vivo are $\alpha-2$ macroglobulin, which is restricted in its sites of activity due to its large size, and the family of specific "tissue inhibitor of MMPs" (TIMPs), naturally occurring proteins specifically inhibiting these proteases and produced by many cell types (6). The TIMP family at present comprises four structurally related members, TIMP-1, -2 , and -3 , and the recently discovered TIMP-4. They have a relative molecular mass ranging from $22 \mathrm{kDa}$ to $30 \mathrm{kDa}$, with $40-50 \%$ sequence identity (7). Of these, TIMP-1 and -2 are secreted in soluble form, whereas TIMP3 is associated with the ECM. The TIMPs bind with high affinity in a 1:1 molar ratio to the catalytic site of active MMPs resulting in loss of proteolytic activity. Moreover, TIMP1 and TIMP-2 can form a specific complex with the zymogens of MMP-9 and MMP-2, respectively $(8,9)$. This interaction has been suggested to provide an extra level of regulation by potentially preventing activation. However, it has recently been shown that TIMP-2 forms a trimolecular complex on the surface of the cell with MT1-MMP and the zymogen form of MMP-2, and regulates the formation and levels of concentration of ac- tive MMP-2 (10).

\section{Acute lung injury and MMPs}

\section{Sources of MMPs during acute lung injury}

By cleaving ECM components, MMPs could play a role in the repair of the alveolar epithelium during acute lung injury. Gelatinases, MMP-2 and MMP-9, are known to degrade almost all basement membrane constituents, including type IV collagen, nidogen and laminin, and gelatins. The ability of lung epithelial cells to produce MMP-9 has been previously demonstrated in sheets of airway lining (11), epithelial cells cultured from human lung explants (12), and by in situ hybridization of normal and neoplastic human lung tissue (13). A study by Buisson and colleagues (14) showed that MMP-9 produced by human surface respiratory epithelial cells from nasal polyps and cultured on type I collagen actively contributed to wound repair in the respiratory epithelium. Moreover, a recent study (15) suggested that MMP-9 controls the migration of repairing human bronchial epithelial cells by remodeling the provisional ECM.

During acute inflammation, polymorphonuclear neutrophils, eosinophils and monocytes and lymphocytes are recruited from the circulation to specific sites within tissue. These recruited cells ingest and kill microorganisms, remove foreign and cellular debris, and assist in tissue repair by modulating the activity of surrounding mesenchymal and endothelial cells. Inflammatory cells perform some of their functions by releasing MMPs into the pericellular space. MMPs are secreted to facilitate clearance of foreign and noxious agents, but, when present in excess, can also destroy the ECM environment, disrupt resident cells, and stimulate further inflammation (16). MMP-2 is synthesized by a wide variety of cells, including fibroblasts, endothelial cells (17) and alveolar epithelial cells $(6,18)$. MMP-9 is pro- 
duced mainly by inflammatory cells such as polymorphonuclear neutrophils, monocytes, macrophages, eosinophils and lymphocytes (19-21), but also, under certain conditions, by cells that synthesize MMP-2, such as endothelial (22) or alveolar epithelial cells (14).

\section{MMPs and LPS-induced acute lung injury}

Lipopolysaccharide (LPS) of Escherichia coli is well known to induce acute pulmonary inflammation associated with polymorphonuclear neutrophil infiltration, and is habitually used in models of inflammation in vivo or in vitro. Numerous studies have focused on the role of MMPs in various models using LPS as a potent inducer of acute lung inflammation. Moreover, the LPS-induced acute inflammation model is well adapted to the study of the pathogenesis of ARDS (23).

LPS exposure leads to an increase of MMP-2 and MMP-9 in bronchoalveolar lavage (BAL) from various animals $(19,24,25)$. Similar results were obtained in rats after subacute hyperoxia (26) or after exposure to ozone (27). Recently, an increase in MMP-9 release has been observed in plasma of normal human subjects given LPS intravenously and the polymorphonuclear neutrophils were identified as the cells responsible for this secretion (28). These observations strongly suggest an involvement of MMP-2 and MMP9 in acute inflammatory processes. Moreover, we have shown in mice that LPSinduced acute inflammation could be reduced by corticosteroid treatment, as observed by inhibition of inflammatory cell infiltration (mainly neutrophils) and reduction of MMP-2 and MMP-9 activity (25). This study demonstrated that corticosteroid may act both on inflammation and tissue remodeling associated with acute lung injury. In vitro studies have shown that stimulation with LPS is responsible for an increase in the release of MMPs, MMP-2 and mainly MMP-9, and TIMPs by human alveolar macrophages (29). After their differentiation towards the macrophage phenotype by phorbol myristate acetate, the human promonocytic U937 cell line can release MMP9 (30).

LPS increases release of MMP-9 and MMP-2 by human bronchial epithelial cells obtained from biopsies, but does not modify TIMP-1 release, suggesting an imbalance in favor of MMPs leading to degradation of ECM components $(12,18)$. Similar results were obtained with rat type II pneumocytes (31). A previous study suggesting a role for MMP-9 in human polymorphonuclear neutrophil migration was done in vitro (32). However, recent findings in mice, both in vitro and in vivo, indicated that MMP-9 is not required for polymorphonuclear neutrophil migration (33). Moreover, we have recently shown that batimastat, a synthetic MMP inhibitor, did not prevent inflammatory cell infiltration induced in mice by LPS aerosol (Corbel M, Caulet-Maugendre S, Germain N, Lagente V and Boichot E, unpublished results). Such controversial results need to be further investigated in order to determine the exact role of neutrophil MMP-9.

\section{MMPs and acute respiratory distress syndrome}

ARDS is a form of acute lung injury characterized by high microvascular permeability, low pressure pulmonary edema, refractory hypoxemia, respiratory failure, and a massive influx of neutrophils. In many patients, fibrotic lesions with collagen deposition develop rapidly after the initial lung injury. Degradation products of type IV collagen have been found in alveolar spaces (34), as well as type III procollagen peptides, markers of collagen synthesis (35), suggesting an increased turnover of ECM during the course of ARDS. In human acute lung injury, mainly in ARDS, an increase in MMPs, 
MMP-2 and MMP-9, as well as TIMP-1 in BAL has been suggested to play a role in basement membrane disruption (36-38). The higher concentration of MMPs might be induced by the increased number of neutrophils in BAL from ARDS patients because MMP-9 is the only type IV collagenase found in neutrophils (39) and because MMP-9 concentrations were significantly correlated with the increase in the number of neutrophils in BAL (36,37). Although macrophages are known to produce MMP-2 and MMP-9, the increase in the number of macrophages was not correlated with the increase in MMP-9. Delclaux and colleagues (38) obtained results which were consistent with those of previous studies and provided data supporting a large imbalance in favor of antiproteases in alveolar spaces. A recent study from our laboratory showed the importance of the MMP-9/TIMP-1 ratio in the dramatic evolution of ARDS. An MMP-9/TIMP-1 ratio >1 would prevent evolution to fibrosis by degradation of ECM components. Indeed, when the MMP-9/TIMP-1 ratio was less than 1, ARDS evolved to fibroproliferation, whereas if the ratio was reversed in favor of MMP-9, we could observe a rapid recovery (Lanchou J, Corbel M, Boichot E, Germain N, Lagente $\mathrm{V}$ and Malledant $\mathrm{Y}$, unpublished data).

In another recent study, we have demonstrated that 10 weeks of repeated LPS exposures lead to the development of interstitial pulmonary fibrosis in mice (40). In this model, the development of fibrosis was associated with increased MMP-2 and MMP-9 activities in BAL. This study showed that chronic repetitive injury of the airways and the consequent persistent lung inflammation favors the development of a repair process which evolves to pulmonary fibrosis. Thus, it seems important to inhibit acute lung injury by preventing inflammatory cascadeinduced structural airway changes such as fibrosis. Further studies are necessary to determine the possible benefits of modulating the tissue remodeling associated with acute lung injury.

\section{References}

1. Anzueto A, Baughman RP, Guntupalli KK, Weg J G, Wiedemann HP, Raventos AA, Lemaire $F$, Long W, Zaccardelli DS \& Pattishall EN (1996). Aerosolized surfactant in sepsis-induced acute respiratory distress syndrome. New England J oumal of Medicine, 334: 1417-1421.

2. Matrisian LM (1990). Metalloproteinases and their inhibitors in matrix remodeling. Trends in Genetics, 6: 121-125.

3. Birkedal-Hansen $\mathrm{H}$, Moore WGI, Bodden MK, Windsor LJ, Birkedal-Hansen B, DeCarlo A \& Engler J A (1993). Matrix metalloproteinases: a review. Critical Reviews in Oral Biology and Medicine, 4: 197-250.

4. Woessner J F (1994). The family of matrix metalloproteinases. Annals of the New York Academy of Sciences, 732: 11-21.

5. Van Wart HE \& Birkedal-Hansen H (1990). The cysteine switch: A principle of regulation of metalloproteinase activity with potential applicability to the entire matrix metalloproteinase gene family. Proceed- ings of the National Academy of Sciences, USA, 87: 5578-5582.

6. Murphy G \& Docherty AJ P (1992). The matrix metalloproteinases and their inhibitors. American J ournal of Respiratory Cell and Molecular Biology, 7: 120-125.

7. Greene J, Wang M, Liu YE, Raymond LA, Rosen C \& Shi YE (1996). Molecular cloning and characterization of human tissue inhibitor of metalloproteinase 4. J ournal of Biological Chemistry, 271: 3037530380.

8. Stetler-Stevenson W, Krutzsch $\mathrm{HC} \&$ Liotta LA (1989). Tissue inhibitor of metalloproteinase (TIMP-2). J ournal of Biological Chemistry, 264: 17374-17378.

9. Wilhelm SM, Collier IE, Marmer BL, Eisen AZ, Grant GA \& Goldberg GI (1989). SV40transformed human lung fibroblasts secrete a $92 \mathrm{kDa}$ type IV collagenase which is identical to that secreted by normal human macrophages. J ournal of Biological Chemistry, 264: 17213-17221.

10. Strongin AY, Collier I, Bannikov G, Marmer
BL, Grant GA \& Goldberg GI (1995). Mechanism of cell surface activation of $72 \mathrm{kDa}$ type IV collagenase. J ournal of Biological Chemistry, 270: 5331-5338.

11. Herbert CA, Arthur MJP \& Robinson $C$ (1996). Augmentation by eosinophils of gelatinase activity in the airway mucosa: Comparative effects as a putative mediator of epithelial injury. British J ournal of Pharmacology, 117: 667-674.

12. Yao PM, Buhler] M, D'Ortho MP, Lebargy F, Delclaux C, Harf A \& Lafuma C (1996). Expression of matrix metalloproteinase gelatinases $A$ and $B$ by cultured epithelial cells from human bronchial explants. J ournal of Biological Chemistry, 271: 1558015589.

13. Carnete-Soler R, Litzky L, Lubensky I \& Muschel RJ (1994). Localization of the 92 $\mathrm{kd}$ gelatinase mRNA in squamous cell and adenocarcinomas of the lung using in situ hybridization. American J ournal of Pathology, 144: 518-527.

14. Buisson AC, Zham J M, Polette M, Pierrot 
D, Bellon G, Puchelle E, Birembaut $P$ \& Toumier J M (1996). Gelatinase B is involved in the in vitro wound repair of human respiratory epithelium. J ournal of Cell Physiology, 166: 413-426.

15. Legrand C, Gilles C, Zham J M, Polette M, Buisson AC, Kaplan H, Birembaut $P \&$ Tournier J M (1999). Airway epithelial cell migration dynamics: MMP-9 role in cellextracellular matrix remodeling. J ournal of Cell Biology, 146: 517-529.

16. Tetley TD (1993). Proteinase imbalance: its role in lung disease. Thorax, 48: 560565.

17. Schnaper HW, Grant DS, Stetler-Stevenson WG, Fridman R, D'Orazi G, Murphy AN, Bird RE, Hoythya M, Fuerst TR \& French DL (1993). Type IV collagenase(s) and TIMPs modulate endothelial cell morphogenesis in vitro. J ournal of Cell Physiology, 156: 235-246.

18. Yao PM, Maitre B, Delacourt C, Buhler J M, Harf A \& Lafuma C (1997). Divergent regulation of $92-\mathrm{kDa}$ gelatinase and TIMP1 by HBECs in response to II-1ß and TNF$\alpha$. American J ournal of Physiology, 273: L866-L874.

19. D'Ortho MP, J arreau PH, Delacourt C, Macquin-Mavier I, Levame M, Pezet S, Harf A \& Lafuma C (1994). Matrix metalloproteinase and elastase activities in LPSinduced acute lung injury in guinea pigs. American J ournal of Physiology, 266: L209-L216.

20. Ohno I, Ohtani H, Nitta Y, Suzuki J, Hoshi $\mathrm{H}$, Honma M, Isoyama S, Tanno Y, Tamura G, Yamauchi K, Nagura H \& Shirato K (1997). Eosinophils as a source of matrix metalloproteinase-9 in asthmatic airway inflammation. American J ournal of Respiratory Cell and M olecular Biology, 16: 212219.

21. Trocmé $C$, Gaudin $P$, Berthier $S$, Barro $C$, Zaoui $P$ \& Morel F (1998). Human B lymphocytes synthesize the $92-k D a$ gelatinase, matrix metalloproteinase-9. J ournal of Biological Chemistry, 273: 2067720684.

22. Partridge $C A$, J effrey JJ \& Malik $A B$ (1993). A 96-kDa gelatinase induced by TNF-alpha contributes to increased microvascular endothelial permeability. American J ournal of Physiology, 265: L438L447.

23. Van Helden HP, Kuijpers WC, Steenvoorden D, Go C, Bruijnzeel PL, Van Eijk M \& Haagsman HP (1997). Intratracheal aerosolization of endotoxin (LPS) in the rat: a comprehensive animal model to study adult (acute) respiratory syndrome. Experimental Lung Research, 23: 297316.

24. Ferry $G$, Lonchampt $M$, Pennel $L$, De Nanteuil G, Canet E \& Tucker GC (1997). Activation of MMP-9 by neutrophil elastase in an in vivo model of acute lung injury. FEBS Letters, 402: 111-115.

25. Corbel $M$, Lagente $V$, Théret $N$, Germain N, Clément B \& Boichot E (1999). Comparative effects of betamethasone, cyclosporin and nedocromil sodium in acute pulmonary inflammation and metalloproteinase activities in bronchoalveolar lavage fluid from mice exposed to lipopolysaccharide. Pulmonary Pharmacology and Therapeutics, 12: 165-171.

26. Pardo A, Barrios R, Maldonado V, Melendez J, Perez J, Ruis V, SeguraValdez L, Sznajder J L \& Selman M (1998). Gelatinases A and B are up-regulated in rat lungs by subacute hyperoxia. American J ournal of Pathology, 153: 833-844.

27. D'Ortho MP, Harf A, Fritsch $P$, Monchaux G \& Lafuma C (1992). Matrix metalloproteinase activities during the 48 hours following an experimental ozone-induced acute lung injury. American Review of Respiratory Disease, 145: A562 (Abstract).

28. Pugin J, Widmer MC, Kossodo S, Liang CM, Preas HL \& Suffredini AF (1999). Human neutrophils secrete gelatinase $B$ in vitro and in vivo in response to endotoxin and proinflammatory mediators. American J ournal of Respiratory Cell and Molecular Biology, 20: 458-464.

29. Shapiro SD, Campbell EJ , Kobayashi DK \& Welgus HG (1991). Dexamethasone selectively modulates basal and lipopolysaccharide-induced metalloproteinase and tissue inhibitor of metalloproteinase production by human alveolar macrophages. J ournal of Immunology, 146: 2724-2729.

30. Saarialho-Kere UK, Welgus HG \& Parks WC (1993). Distinct mechanisms regulate interstitial collagenase and 92-kDa gelatinase expression in human monocytic-likecells exposed to bacterial endotoxin. J ournal of Biological Chemistry, 268: 1735417361.

31. D'Ortho MP, Clerici C, Yao PM, Delacourt C, Delclaux C, Franco-Montoya ML, Harf A \& Lafuma C (1997). Alveolar epithelial cells in vitro produce gelatinases and tissue inhibitor of matrix metalloproteinase2. American J ournal of Physiology, 273: L663-L675.

32. Delclaux C, Delacourt C, D'Ortho MP,
Boyer V, Lafuma C \& Harf A (1996). Role of gelatinase $B$ and elastase in human polymorphonuclear neutrophil migration across basement membrane. American J ournal of Respiratory Cell and Molecular Biology, 14: 288-295.

33. Betsuyaku, T, Shipley J M, Liu Z \& Senior RM (1999). Gelatinase B deficiency does not impair neutrophil migration in vivo. American J ournal of Respiratory Cell and Molecular Biology, 20: 1303-1309.

34. Kondoh Y, Taniguchi H, Taki F, Takagi K \& Satake T (1992). 7S collagen in bronchoalveolar lavage fluid of patients with adult respiratory distress syndrome. Chest, 101: 1091-1094.

35. Clark J G, Milberg J A, Steinberg KP \& Hudson LD (1995). Type III procollagen peptide in the adult respiratory distress syndrome. Association of increased peptide levels in bronchoalveolar lavage fluid with increased risk for death. Annals of Internal Medicine, 122: 17-23.

36. Ricou B, Nicod L, Lacraz S, Welgus HG, Suter PM \& Dayer J M (1996). Matrix metalloproteinases and TIMP in acute respiratory distress syndrome. American J ournal of Respiratory and Critical Care Medicine, 154: 346-352.

37. Torii K, lida KI, M iyazaki Y, Saga S, Kondoh Y, Taniguchi H, Taki F, Takagi K, Matsuyama M \& Suzuki R (1997). Higher concentrations of matrix metalloproteinases in bronchoalveolar lavage fluid of patients with adult respiratory distress syndrome. American J oumal of Respiratory and Critical Care Medicine, 155: 43-46.

38. Delclaux C, D'Ortho MP, Delacourt C, Lebargy F, Brun-Buisson C, Brochard L, Lemaire F, Lafuma C \& Harf A (1997). Gelatinases in epithelial lining fluid of patients with adult respiratory distress syndrome. American J ournal of Physiology, 272: L442-L451.

39. Masure S, Proost P, Van Damme J \& Opdenakker G (1991). Purification and identification of $91-\mathrm{kDa}$ neutrophil gelatinase. Release by the activating peptide interleukin-8. European J ournal of Biochemistry, 198: 391-398.

40. Corbel M, Théret N, Caulet-Maugendre S, Germain N, Lagente V, Clément B \& Boichot E (1998). Increased activity of matrix metalloproteinase- 9 (92 kDa gelatinase) and neutrophil recruitment following chronic exposure to endotoxin in the mouse. American J ournal of Respiratory and Critical Care Medicine, 157: A567 (Abstract). 